\title{
Okul Terkinin Maliyeti: Kamu Gelirleri Kapsamında Türkiye Değerlendirmesi \\ (Araştırma Makalesi)
}

The Cost of School Dropout: Turkey Assessment in the Context of Public Revenues

Doi: 10.29023/alanyaakademik. 847747

\section{Doğan BAKIRTAŞ}

Doç. Dr., Manisa Celal Bayar Üniversitesi, Salihli İ̈BF, Maliye Bölümü

dogan.bakirtas@cbu.edu.tr

Orcid: 0000-0002-9189-3451

\section{Metin NAZLIOĞLU}

Araştırma Görevlisi, Manisa Celal Bayar Üniversitesi, Salihli İ̈BF, Maliye Bölümü metin.nazlioglu@cbu.edu.tr

Orcid: 0000-0002-4926-298X

Bu makaleye atıfta bulunmak için: Bakırtaş, D. \& Nazlıoğlu, M. (2021). "Okul Terkinin Maliyeti: Kamu Gelirleri Kapsamında Türkiye Değerlendirmesi”, Alanya Akademik Bakıs, 5(2), Sayfa No.671691.

\author{
Anahtar kelimeler: \\ Okul Terki, Vergi \\ Gelirleri, Kaти Gelir \\ Kaybı
}

Makale Geliş Tarihi: 27.12.2020

Kabul Tarihi:

28.01.2021

\section{Keywords:}

School Dropout, Tax Revenues, Public Revenue Loss

\section{ÖZET}

Okul terki; işsizlik, ömür boyu düşük kazanç ve düşük yaşam memnuniyeti gibi bazı bireysel maliyetlere yol açmaktadır. Bu maliyetlerin yanı sıra kamu gelirleri üzerinde de olumsuz bir etkiye sahiptir. Bu çalışma, okul terkinin vergi ve parafiskal gelirler üzerindeki aşındırıcı etkisine odaklanmaktadır. Kamu gelir kaybl; (1) tüm ögrencilerin lise mezunu olmalart ve (2) tüm ögrencilerin meslek lisesi mezunu olmaları şeklinde iki senaryo kapsamında değerlendirilmiştir. Bulgular; lise mezuniyeti ve meslek lisesi mezuniyeti eksikliğinden dolayı öğrenci başına strasıyla, yıllık 284.8 dolar ve 1,837 dolar kamu gelir kaybinı ortaya koymaktadır.

\section{ABSTRACT}

School dropout leads to some individual costs, such as unemployment, low lifetime earnings and also low life satisfaction. Besides these costs, it has a negative impact on public revenues. This study focusses on the detrimental effect of school dropout on tax and parafiscal revenues. Public revenue loss is projected under two scenarios: (1) all students graduate from a high-school and (2) all students graduate from a vocational school. The findings indicate an annual public revenue loss of $\$ 284.8$ and $\$ 1,837$ per student dropout for the lack of high school graduate and vocational high school graduate, respectively. 


\section{GİRIŞ}

Eğitim meselesi tüm toplumu ilgilendiren bir olgudur. Yaşam kalitesinin yükselmesi, elde edilen gelirin artması ve yüksek istihdam düzeyi gibi bireysel kazanımların yanında toplumsal refah, ekonomik büyüme ve beşeri sermaye birikimi artışı gibi toplum geneline yayılan kazanımlara pozitif katkılar sağlamaktadır. Dolayısıyla eğitim seviyesinin ve kalitesinin artması; bireyler ile toplum üzerinde doğrudan ve/veya dolaylı birçok kazanımın ortaya çıkmasında kilit bir rol üstlenmektedir. Eğitim seviyesinin düşmesi durumunda ise söz konusu kazanımlar birer maliyet unsuruna dönüşmekte ve bireysel olarak başlayan bu dönüşüm, toplumun geneline yayılarak ekonomik, sosyal ve kültürel dinamikleri negatif yönde etkilemektedir.

Eğitim seviyesinin düşmesine ve bireylerin eğitim kalitesinin azalmasına neden olan başlıca faktörlerden biri de okul terkidir. Okul terki, zorunlu eğitim sürecinin dışına çıkmak ve/veya bir öğrencinin orta öğretim seviyesini tamamlamadan okuldan ayrılması olarak tanımlanabilir. Demografik, ailevi, sosyal ve eğitim ile ilgili olmak üzere sıralanan okul terki nedenlerinin önlenmesine yönelik ulusal ve uluslararası düzeyde birçok politika hayata geçirilmektedir. Ancak okul terkine ilişkin çalışmalar ve tasarlanan politikalar genellikle okul terkinin nedenleri üzerinde yoğunlaşmakla birlikte bu durumun ortaya çıkardığı maliyetler nispeten göz ardı edilmektedir.

Okul terkinin bireysel ve sosyal maliyetlerine bakıldığında işsizlik düzeyinin artması ve elde edilen ücret gelirinin düşmesi gibi etkilerin bireysel açıdan, suç oranlarının artması ve halk sağlığı hizmetleri gibi kamu hizmetlerine olan talebin artması vb. gibi etkiler ise ise toplumsal açıdan maliyetleri oluşturmaktadır. Kamu harcamaları açısından sağlık hizmetleri gibi kamu hizmetlerine olan talebin artışı sağlık harcamalarını artırmakta, suç oranlarının artışı adalet hizmetlerine yönelik harcamaları artırmakta ve işsizlik oranlarının artışı ise sosyal refah harcamalarını artırmaktadır. Okul terkinin kamu harcamalarına yönelik olası maliyetleri yanında kamu gelirleri açısından da negatif etkileri bulunmaktadır. Bu noktada, bireylerin eğitimlerini tamamlamadan eğitim dışı kalmaları durumunda elde edecekleri muhtemel ücret geliri de -söz konusu sektördeki yetkinliklerin yeterli düzeyde olmaması nedeniyledüşmektedir. Ücret gelirlerinin düşük olması ise kamu gelirlerinin en önemli kaynağı olan vergi gelirlerinin de düşmesine yol açmaktadır. Vergi gelirlerinin yanında elde edilen ücret geliri üzerinden çalışan ve işveren payı olarak tahsil edilen sosyal güvenlik kurumu (SGK) primleri de azalmaktadır. Parafiskal gelir olarak kamu bütçelerinde yer alan bu gelir kalemi de okul terki neticesinde -daha düşük ücret geliri elde edilmesi nedeniyle- azalmaktadır.

Türkçe literatürde öncü olan bu çalışmada, okul terkinin kamu bütçesinde meydana getirdiği gelir kaybı ortaya koyulmaya çalışılmıştır. Bu noktada; özellikle okul terki neticesinde daha düşük düzeylerde ücret geliri elde edilmesinden hareketle daha düşük vergi geliri ve SGK priminin olması durumu ele alınarak okul terkinin olmadığı durum, iki farklı mezuniyet türü çerçevesinde (lise mezunu/meslek lisesi mezunu) 2018 yılı verileri ile Türkiye kapsamında değerlendirilmiştir. Çalışmanın birinci bölümünde kavramsal çerçeve ortaya koyulmuş, sonraki bölümde ise okul terkinin nedenleri ve maliyetlerine değinilmiştir. Çalışmanın son bölümünde ise okul terki sayıları belirlendikten sonra belirli kriterler kapsamında lise ve meslek lisesi mezuniyet durumunun, ilkokul/ortaokul mezuniyet durumuna göre elde edilen ücret geliri ile ilişkili olarak kamu gelir kaybı ortaya koyulmuştur. 


\section{OKUL TERKİ KAVRAMI}

Okul terkinin tanımı, temel alınan eğitim gruplarına ve neden olan faktörlere göre çeşitlilik göstermektedir. Varner (1967) okul terkini; ölüm haricinde bir gerekçe dolayısıyla, herhangi bir diploma almadan ve herhangi başka bir okula transfer olmadan eğitim hayatının sonlandırılması olarak tanımlamaktadır. Dekkers ve Claassen (2001) ise okul terkini iki şekilde açıklamaktadır. İlk tanım, ortaöğretimin ilk aşamasının sertifika alınmadan terk edilmesi şeklinde yapılmaktadır. Diğer tanım ise yeterlilik düzeyleriyle ilgilidir. Bu tanıma göre iki çeşit okul terki vardır; genel ortaöğretimin ilk aşamasına ait olan sertifikaya sahip olmak ancak mesleki temel yeterlilikleri sahip olmamak ile genel eğitim sertifikasına sahip olmamak (Dekkers ve Claassen, 2001: 341-342). Avustralya'da okulu erken terk edenler, ortaöğretimi tamamlamayanlar ve daha sonra başka bir resmi eğitim ya da öğretim faaliyetinde bulunmayanlar olarak tanımlanmaktadır (NATSEM, 1999). Eurostat ve Avrupa Komisyonu tarafından yapılan tanımlamaya göre okul terki, 18 ile 24 yaş arasındaki bir bireyin en düşük orta öğretim düzeyine sahip olması ve eğitim-öğretim faaliyetleri ile ilişkisinin kesilmesi durumunda ortaya çıkmaktadır (European Commission, 2011).

Okul terki kavramı için geniş bir tanım yapmak gerekirse; eğitimine devam eden bir öğrencinin çeşitli kişisel nedenlerden (evlilik, yaş farkı, hastalık, fiziksel engellilik, kronik sağlık problemleri), okul temelli nedenlerden (okula uyum, okuldan atılma/uzaklaştırılma, okulu sevmeme, düşük akademik başarı) ve aile ile sosyal çevre temelli nedenlerden (ailenin kültür düzeyi, ebeveynlerin sosyoekonomik durumu, ebeveynlerin eğitim düzeyi, arkadaşlık bağları, bölgesel ilişkiler, akran baskısı, bağımlılık) dolayı içinde bulunduğu eğitim basamağını tamamlayamamasidir (Smith ve Ament, 1990).

Literatürde; erken okul terki (early school leaving, ESL), eğitim-öğretimden erken ayrılma (early leaving from education and training, ELET) ve okul terki (school dropout) şeklinde çeşitli kavramlar bulunmaktadır. Karışıklığı önlemek ve tutarlılık adına çalışmada, tüm bu kavramları temsil eden okul terki kavramı kullanılmıştır.

Türkiye'de Milli Eğitim Bakanlığı (MEB) e-okul sistemi; “ortaöğretimde ikinci kez sınıf tekrarına kalan, öğrenimine açık liseye kayıtlı olarak devam eden, öğrenim hakkını kullanmayan (iki ĕgitim-ögretim yılı ile sınırll), kendi isteği ile öğrenim dışına çıkan, yurt dışına çıkan ve vefat eden" tüm öğrencileri okul terki tanımlaması içine almaktadır (MEB, 2013: 35).

Okul terki ile uluslararası düzeyde mücadele veren en önemli kuruluşlardan biri OECD'dir. OECD tarafindan yapılan tanımlamalara göre, okul terkinin iki boyutu bulunmaktadır. Öncelikle okul terki, herkese kaliteli eğitim sağlayamayan bir eğitim sistemi başarısızlığıdır. Diğer yandan, bir öğrencinin gerekli asgari standartlara sahip olamaması veya okulu bırakması nedeniyle -bireysel bir bakış açısıyla- bu durum ortaya çıkmaktadır. Eğitim ile ilişkili başarısızlıklar ve eşitsizlikler özünde birbirlerine bağlıdır. Okul başarısızlığının üstesinden gelebilmek için eğitimde eşitliğin yanında ortaya çıkan yüksek sosyal ve ekonomik maliyetlerin de en az indirilmesi gerekmektedir (OECD, 2010: 9).

Eurostat tarafından istatistiksel olarak ortaya koyulan okul terki oranları; en düşük ortaöğretim düzeyine sahip olması ile daha ileri eğitim-öğretim faaliyetinde bulunmayan ve anketten önceki son dört hafta boyunca ileri eğitim-öğretim faaliyetinde bulunmayan 18-24 yaş arasındaki 
nüfusun bir yüzdesi olarak hesaplanmaktadır. Avrupa Birliği üye ve aday ülkelerdeki okul terki oranları Tablo 1'de sunulmuştur.

Tablo 1: Avrupa Birliği Üye ve Aday Ülkelerde Okul Terki Oranları (\%)

\begin{tabular}{|c|c|c|c|c|c|c|c|}
\hline & 2011 & 2018 & 2019 & & 2011 & 2018 & 2019 \\
\hline Türkiye & 41.9 & 31 & 28.7 & Macaristan & 11.4 & 12.5 & 11.8 \\
\hline Belçika & 12.3 & 8.6 & 8.4 & Malta & 22.7 & 17.4 & 16.7 \\
\hline Bulgaristan & 11.8 & 12.7 & 13.9 & Hollanda & 9.2 & 7.3 & 7.5 \\
\hline Çekya & 4.9 & 6.2 & 6.7 & Avusturya & 8.5 & 7.3 & 7.8 \\
\hline Danimarka & 10.3 & 10.4 & 9.9 & Polonya & 5.6 & 4.8 & 5.2 \\
\hline Almanya & 11.6 & 10.3 & 9.8 & Portekiz & 23 & 11.8 & 10.6 \\
\hline Estonya & 10.6 & 11.3 & 9.8 & Romanya & 18.1 & 16.4 & 15.3 \\
\hline İrlanda & 11.1 & 5 & 5.1 & Slovenya & 4.2 & 4.2 & 4.6 \\
\hline Yunanistan & 12.9 & 4.7 & 4.1 & Slovakya & 5.1 & 8.6 & 8.3 \\
\hline İspanya & 26.3 & 17.9 & 17.3 & Finlandiya & 9.8 & 8.3 & 7.3 \\
\hline Fransa & 12.3 & 8.9 & 8.2 & İsveç & 6.6 & 7.5 & 6.5 \\
\hline Hirvatistan & 5 & 3.3 & 3.0 & B. Krallık & 14.9 & 10.7 & 10.9 \\
\hline İtalya & 17.8 & 14.5 & 13.5 & İzlanda & 19.7 & 21.5 & 17.9 \\
\hline G. Kibris & 11.3 & 7.8 & 9.2 & Norveç & 16.6 & 9.9 & 9.9 \\
\hline Letonya & 11.6 & 8.3 & 8.7 & İsviçre & 6.3 & 4.4 & 4.4 \\
\hline Litvanya & 7.4 & 4.6 & 4.0 & Karadağ & 7.2 & 4.6 & 5.0 \\
\hline Lüksemburg & 6.2 & 6.3 & 7.2 & Surbistan & 8.5 & 6.8 & 6.6 \\
\hline K. Makedonya & 13.5 & 7.1 & 7.1 & & & & \\
\hline
\end{tabular}

Kaynak: Eurostat, 2020.

Son yıllarda Avrupa Birliği (üye ülkeler/aday ülkeler toplamda 35 ülke) düzeyinde okul terki oranları genel olarak düşüş seyri izlemektedir. 2011 yılından bu yana Macaristan, Lüksemburg, Slovenya ve İsveç dışında, tüm ülkelerde okul terki oranlarında düşüş meydana gelmiştir. En yüksek düşüşler Türkiye, Yunanistan, İrlanda, İspanya, Portekiz'de yaşanmıştır. Ancak tüm bu düşüşlere rağmen Türkiye, İspanya ve Portekiz'de okul terki oranları hali hazırda yüksek seviyededir.

Avrupa Birliği ülkeleri 2000'li yılların başından bu yana okul terki ile mücadele etmek için bir dizi politika hayata geçirmektedir. Avrupa Birliği Komisyonu, üye ülkelerle birlikte okul terkinin azaltılması için kapsamlı stratejiler oluşturmakta ve uygulamaya koymaktadır. Bu stratejiler neticesinde başarılı sonuçlar elde edilmiş ve birçok ülkede 2020 yılı hedefi olarak belirlenen \%10 sınırına erişilmiştir. Avrupa Birliği'nde 2019 yılında 18-24 yaş bireyler arasında okul terki oranı \% 10.2'dir. Okul terki oranının; erkek nüfus içinde \% 11.9 , kadın nüfus içinde ise \% 8.4 olduğu söylenebilir (Eurostat, 2020).

\section{OKUL TERKININ NEDENLERİ}

Okul terkine neden olan faktörlere ait literatür oldukça geniş ve kapsamlıdır. Psikoloji, sosyoloji, antropoloji ve ekonomi gibi birçok sosyal bilim disiplini temelinde, okul terkine neden olan faktörleri açıklayan bir dizi teori bulunmaktadır. Kaufmann ve Lewis (1968) okul terkine neden olan faktörleri kültürel yoksunluk, kültürel gruplar arasında ortaya çıkan kültürel uyumsuzluk, sosyoekonomik durumu düşük öğrencilere ulaşmada okulun rolünü de vurgulayan sosyoekonomik boyut ve mesleki eğitim alanı temelinde ele almıştır. Weis vd. 
(1989) kötü sosyoekonomik şartları, öğrencilerin sahip olduğu düşük özsaygı (self-esteem) düzeyini ve yoksulluğu okul terkine neden olan en önemli faktörler arasında göstermiştir. Rumberger'e (2001) göre hem öğrenci hem de ailesi, okul ve diğer toplumsal ortamlarla ilgili bir dizi faktörden etkilenmektedir. Rumberger (2001) bireysel ve kurumsal faktörlerin altını çizmiş ve bireysel faktörleri davranışlar, değerler ve tutumlar çerçevesinde; kurumsal faktörleri ise aile, akran ve sosyal çevre ilişkileri çerçevesinde irdelemiştir. Eğitime Erişim, Geçişler ve Eşitlik Araştırmaları Konsorsiyumu (CREATE) (2009) okula bağlı nedenler, bireysel nedenler, aile ve çevreyle ilgili nedenler ile sosyoekonomik nedenler üzerinde yoğunlaşmıştır.

Varner'in (1967) yaptığı sınıflandırma ise gönüllülük esasına dayanmaktadır. Gönüllü olmayan okul terkine neden olan faktörleri fiziksel engellilik, kronik hastalık ve uzaklaştırma/atılma gibi faktörler oluşturmaktadır. Bir işte çalışma zorunluluğu, aileye destek verme yükümlülügü ve evlenme gibi faktörler de gönüllü faktörler olarak ifade edilmektedir.

Rumberger vd. (1990) okul terkine neden olan faktörleri demografik faktörler, okul temelli faktörler, aile temelli faktörler ve bireysel faktörler şeklinde bir sinıflandırmaya tabi tutmaktadır. Bireysel ve sosyal faktörlerin yanı sıra Bridgeland vd. (2006) okulda görev yapan çalışanlar ile öğrenciler arasında çıkan çatışmaların, akademik ilerlemede başarı elde edememenin, öğrencinin okul ile uyumsuzluğunun da okul terkine neden olan faktörler olduğunu belirtmektedir.

Batsche (1985) öğrencilerin neden liseyi terk ettiklerini tam anlamıyla değerlendirmenin zorluğundan bahsetmekle birlikte öğrencilerin genellikle sosyal olarak kabul edilebilir açıklamalar yaptığını ifade etmektedir. Erkek öğrenciler kötü notlar, okulu sevmeme, bir işte çalışma zorunluluğu, öğretmenlerle anlaşamama, atılma/uzaklaştırma ve aileyi ekonomik olarak destekleme zorunluluğu gibi faktörlerin; kız öğrenciler ise evlilik, okulu sevmeme, hamilelik, bir işte çalışma zorunluluğu ve öğretmenlerle anlaşamama gibi faktörlerin okul terkine neden olduğunu ifade etmektedir (Batsche, 1985; Resta ve Temple, 1978). Batsche (1985) ayrıca okul terkinin arkasında yatan gerçek nedenlerin yalnız hissetme (tecrit, izolasyon), okuldan sıkılma, uyumsuzluk ve ilgisizlik olduğunu da ileri sürmektedir. Okul terkinin nedenleri olarak ifade edilen faktörler Tablo 2'de özetlenmiştir.

Tablo 2: Okul Terkine Neden Olan Faktörler

\begin{tabular}{llll}
\hline $\begin{array}{l}\text { Demografik } \\
\text { Faktörler }\end{array}$ & Ailevi Faktörler & $\begin{array}{l}\text { Kişisel/Sosyal } \\
\text { Psikolojik Faktörler }\end{array}$ & $\begin{array}{l}\text { Eğitim ile İlgili } \\
\text { Faktörler }\end{array}$ \\
\hline -Düşük & -Okula devam & -Evlilik/Hamilelik & -Düşük akademik \\
sosyoekonomik & yönünde yetersiz & -İhmal & performans \\
düzeye sahip azınlık & destek & -Yıkııı davranış & -Okuma ve matematikte \\
üyesi olma & -Öğrencinin okul & bozukluğu & zayıf temel beceri \\
-Tek ebeveynli evde & aktivitelerine yönelik & -düşük benlik düzeyi & -Okul çalışmalarına \\
yaşama & ilgisizlik & ve sosyal olgunluk & ilgisizlik \\
-Ebeveynlerin düşük & -Gelecekteki & -Hayatının & -Devamsızlık \\
eğitim seviyesi & eğitim/istihdam & kontrolünün elinde & -Eğitim konusunda \\
-Erkekler & planları nedeniyle sık & olmadığına dair inanç & ilgisizlik \\
-Coğrafi Bölge & sı yaşanan & & -Sinıf tekrarı \\
-Devlet okuluna & tartışmalar & & -Müfredat dışı \\
devam etme & & & faaliyetlere daha az \\
& & & katılım \\
\hline
\end{tabular}


Kaynak: Smith ve Ament, 1990: 7-8.

Öğrencinin okulu terk etmesine neden olan bireysel temelli faktörler bireylerin davranışlarından, tutumlarından, değer yargılarından ve geçmiş yaşantılarından etkilenen faktörlerdir. Öğrencinin sahip olduğu duygusal yapı, okul personeli ile kurduğu ilişkileri yakından etkilemektedir. Okul akademik ve idari personeli ile ögrenci arasında meydana gelen etkileşim esnasında, öğrencinin sahip olduğu düşük benlik düzeyi, yabancılaşma, güvensizlik içinde hissetme gibi duygu durumlarının okul terkine neden olduğu ifade edilmektedir (Mertens vd., 1982: 26; Smith ve Ament, 1990: 8). Ayrıca Smith ve Ament (1990) öğrencilerin sahip olduğu sosyal olgunluk ve hayatları ile ilgili kararların kendi kontrolleri altında olmadığı inancı gibi faktörlerin de okul terki kararının alınmasında bir etkiye sahip olduğunu vurgulamaktadır.

Evlilik ve hamilelik gibi durumlar da okul terkine neden olabilen faktörler arasında gösterilmektedir (Dahl, 2005; Resta ve Temple, 1978; Smith ve Ament, 1990). Kaliforniya eyaletinde yapılan ve 2002-2004 yıllarını kapsayan okul terki anketinde, okul terkine neden olan faktörler arasında \%28 oran ile hamilelik faktörü de yer almaktadır (Rotermund, 2007). Erken yaşta evlenen veya hamilelik dolayısıyla okulu terk etmek durumunda kalan öğrenciler, yaşamlarının ileri safhalarında yetersiz eğitim aldıkları için ekonomik ve sosyal bir dizi sorunla karşılaşabilmektedir.

Alkol ve uyuşturucu bağımlılığı gibi kötü alışkanlıklar da öğrencilerin okuldan uzaklaşmasına neden olmaktadır. Öğretmenler ile anlaşamama, hatta fiziksel müdahaleye varan anlaşmazlıklar ve okul içinde diğer öğrencilerle kavga gibi faktörler de okul terkinin nedenleri arasında yer almaktadır (Batsche, 1985).

Aile yapısı açısından birçok durum da okul terki problemi üzerinde önemli bir etkiye sahiptir. Rumberger (1995), öğrencilerin ailelerinin mesleki durumları ve/veya diğer çeşitli nedenlerden dolayı sık sık taşınmak durumunda kalması gibi faktörlerin de okul terki riskini arttırdığını ifade etmektedir. Ayrıca ailenin genişliği, sosyoekonomik durumu, sahip olduğu inanç ve anadil gibi faktörlerin de okul terki kararını etkilediği ifade edilmektedir (Mertens vd., 1982). Ebeveynlerin sosyoekonomik durumu, eğitim durumu, mesleği ve çocukları ile kurmuş oldukları iletişimin kalitesi de okul terki kararını etkileyen faktörler arasındadır (Batsche, 1985). Ayrıca ebeveynlerin kendi aralarında ilişkilerinin düzensizliği ve parçalanmış bir aile yapısının olması da diğer ailevi faktörler arasında gösterilmektedir (Rumberger, 1987).

Öğrencilerin okula devam durumu da okul terkine neden olan faktörler arasında gösterilmektedir (Rotermund, 2007). McNeal'e (1997) göre öğrencinin devam durumunu belirleyen önemli faktörlerden biri, öğrencinin yaşamını sürdürdüğü çevrenin sosyoekonomik düzeyidir. Daha düşük düzeye sahip bölgelerden gelen çocuklarda okul terki oranının daha yüksek olduğu ifade edilmektedir. Ayrıca olumsuz ve kötü şartlara sahip bölgelerde yaşayan öğrencilerin suça karışma eğilimleri daha yüksektir. Dolayısıyla suça karışma sonucunda tutuklanma ve alıkonulma gibi durumlar ortaya çıkmakta ve öğrenciler uzun süreli devamsızlık ve hatta sinıf tekrarı yapmak zorunda kalabilmektedir (Batsche, 1985; Anderson, 2014; Aslund vd., 2018).

Öğrencilerin arkadaş grupları ve akran grubunun da okul ile ilgili kararlarda etkili olduğu belirtilmektedir (Kaufman ve Lewis, 1968). Arkadaşları tarafından dışlanan öğrencinin okulu terk etme riskinin daha yüksek olduğu ifade edilmekle birlikte arkadaşlık bağlarının önemli bir faktör olduğunun da altı çizilmektedir (Carbonaro ve Workman, 2013). 


\section{OKUL TERKININ MALIYETI}

Okul terkinin maliyetlerini detaylandırmadan önce yüksek eğitim seviyesinin avantajlarına/getirilerine değinmek faydalı olacaktır. Söz konusu avantajlar özel, mali ve sosyal avantajlar olmak üzere sinıflandırılmaktadır (Belfield, 2008: 47; Brunello ve De Paola, 2014: 27). Eğitim seviyesinin yükselmesi ile birlikte ortaya çıkan olası avantajlar Tablo 3 'te sunulmuştur.

Tablo 3: Yüksek Eğitim Seviyesinin Avantajları

\begin{tabular}{ll}
\hline \multirow{2}{*}{ zel Avantajlar } & Kazanç artışı \\
& Yaşama eklentisinin artması (+) \\
& Hanehalkının verimlilik artışı (+) \\
& Eğitim ücretleri (-) \\
\hline \multirow{3}{*}{ Mali Avantajlar } & Vergi tahsilatında artış \\
& Devlet sağlık programlarına duyulan talebin azalma (+) \\
& Cezai adalet ile ilgili kamu harcamalarının azalması (+) \\
& Sosyal yardım talebinin azalması (+) \\
& Eğitim sübvansiyonları $(-)$ \\
\hline \multirow{3}{*}{ Sosyal Avantajlar } & Verimliliğin yarattı̆̆ dışsallıklar $(+)$ \\
& Suç oranlarında azalma $(+)$ \\
& Sağlığın toplumsal değeri $(+)$ \\
\hline
\end{tabular}

Kaynak: Belfield, 2008: 47.

Okul terki, toplumsal açıdan birçok olumsuzluğa neden olan bir eğitim sistemi problemidir. Eğitimlerini tamamlamadan ve/veya yeterli düzeyde akademik birikim elde etmeden okulu terk edenler, sahip oldukları yetersiz eğitim seviyesi dolayısıyla yetişkinliğe geçişte bir dizi ekonomik ve sosyal refah sınırlamaları ile mücadele etmek durumunda kalmaktadır (Rumberger, 1987).

Okul terki olgusu genellikle politika yapıcılar tarafından negatif olarak değerlendirilmektedir. Bunun nedeni, okulu terk edip eğitimlerini tamamlayamayan bireylerin işsizliğe neden olduğunu ve temel eğitime sahip olamadıkları için hayatlarını sağlıklı bir şekilde idame ettiremeyeceklerini düşünmeleridir. Dolayısıyla birçok Batılı ülkede okul terki, başta eğitim alanı olmak üzere birçok alanda en temel problemlerden biri olarak gösterilmektedir (Dekkers ve Claassen, 2001: 342).

Okul terki, eğitim sisteminin başarısızlığının yanında modern yaşamın gerekliliklerini yerine getiremeyen bireylerin de başarısızlığı olarak değerlendirilmelidir. Okul terki problemi genellikle sosyoekonomik düzeyi düşük ailelerde yetişmiş olan gençlerde görülmektedir. Bir lise diploması olmadan ve okuma-yazma becerisini geliştiremeden okulu terk eden gençler, uzun vadede barınma, sağlık ve istihdam gibi sosyal refah programları üzerinde bir yükün ortaya çıkmasına neden olmaktadır (Catterall, 1985). Lise diplomasına sahip olmak birçok ülkede işe alım süreçlerinde büyük bir öneme sahiptir. İşverenler açısından bir değerlendirme kriteri olarak kullanılmaktadır. Okul terki nedeniyle lise diploması sahibi olamayan öğrencilerin iş hayatına entegre olurken bir dizi sorunla karşılaştığı ve lise diploması sahibi bireylerden daha az ücret geliri elde ettikleri ifade edilmektedir (Chaplin ve Lerman, 1997). 
Yeterli düzeyde akademik bir eğitim almadan ve okuma yazma becerisi kazanmadan okulu terk eden bireyler işsizlik, suça karışma, sosyal çevresi tarafından dışlanma, sağlık hizmetlerine erişimde zorluklarla karşılaşma ve sosyal yardımlara ihtiyaç duyma gibi birçok durumla karşı karşıya kalmaktadır. Dolayısıyla okul terkinin bireysel ve ekonomik maliyetlerinin yanında sosyal maliyetleri de bulunmaktadır (Rumberger ve Lim, 2008).

\section{Tablo 4: Okul Terkinin Maliyetleri}

\begin{tabular}{|c|c|c|}
\hline Özel & $\begin{array}{l}\text {-Daha yüksek işsizlik oranı } \\
\text {-Daha yüksek işsizlik süresi } \\
\text {-Daha düşük başlangıç/ömür boyu kazanç } \\
\text {-Daha düşük sağlık durumu }\end{array}$ & $\begin{array}{l}\text {-Daha az riskten kaçınma } \\
\text {-Daha az yaşam boyu öğrenme } \\
\text { katılımı } \\
\text {-Çocuk yetiştirmede yetersizlikler } \\
\text {-Daha düşük yaşam memnuniyeti }\end{array}$ \\
\hline Sosyal & $\begin{array}{l}\text {-Suç oranlarında artış } \\
\text {-İş arkadaşları üzerinde olumsuz etki } \\
\text {-Düşük ekonomik büyüme oranı } \\
\text { - Daha düşük sosyal uyum }\end{array}$ & $\begin{array}{l}\text {-Ebeveynler/çocuklar üzerindeki } \\
\text { kuşaklararası etkinin azalması } \\
\text {-Daha düşük halk sağlı̆̆ı } \\
\text {-Daha yüksek işsizlik oranı }\end{array}$ \\
\hline Mali & $\begin{array}{l}\text {-Daha düşük vergi gelirleri } \\
\text {-Yüksek işsizlik dolayısıyla artan sosyal } \\
\text { yardımlar } \\
\text {-Daha yüksek sağlık harcamaları }\end{array}$ & $\begin{array}{l}\text {-Daha yüksek güvenlik harcamaları } \\
\text { - Daha yüksek ceza/adalet harcamaları }\end{array}$ \\
\hline
\end{tabular}

Kaynak: Psacharopoulos, 2007: 7.

Okul terkinin sosyal açıdan neden olduğu sorunlardan biri, suç oranlarının artmasıdır. Suç oranlarının artması hem sosyal hem de ekonomik/mali bir sorun olarak gösterilmektedir. Suçun önlenebilmesi için kamu idaresi tarafından birçok (güvenlik, adalet vb.) harcama yapılması gerekmektedir. Moretti (2005) 20-60 yaş arasında lise eğitimini tamamlayan erkeklerin oranında meydana gelen \%1'lik bir artışın, suç ile ilgili kamusal maliyetlerde 1.4 milyar dolar tasarruf sağladığını ifade etmektedir. Ayrıca okulu terk etmeden eğitim-öğretimde geçirilen her ekstra yılın; toplam nüfus içinde cinayetlerin $\% 30$ ve motorlu araç hırsızlığının ise \%20 azalmasına neden olduğunu belirtmektedir. Snyder ve Sickmund (1999) okul terki nedeniyle ortaya çıkan suça bulaşma ve uyuşturucuya eğilim konularını ele aldıkları çalışmalarında, okulu terk edip sonrasında suça ve uyuşturucuya buluşan gençlerin yarattığı sosyal sorunların 1.7 ila 2.3 milyon dolara mal olduğunu ifade etmektedir.

Eğitim seviyesi ile sağlık durumu arasında yakın bir ilişkinin olduğu da birçok çalışmada vurgulanmaktadır. Cutler ve Lleras-Muney (2006) lise mezunlarının, lise düzeyinde okulu terk edenlere göre sağlık durumlarının daha iyi ve ölüm oranlarının daha düşük olduğunu ifade etmekle birlikte yükseköğretimin herhangi bir basamağından mezun olanların durumunun ise çok daha iyi olduğunu vurgulamaktadır. Levin vd., (2007) çalışmalarında eğitim seviyesi artışının, kamu sağlık hizmetleri sunumunda önemli tasarrufların yapılabilmesine olanak sağlayacağını ileri sürmektedir. Bu noktada, daha yüksek eğitim seviyesine sahip olanların kamu sağlık programlarından daha az faydalanması, okulu terk edenlere nazaran daha muhtemel olduğu söylenebilir. Bu durumun gerekçesi, yüksek eğitimli bireylerin daha iyi sağlık sigortası imkânı sunan mesleklere sahip olması şeklinde açıklanmaktadır. Aynı 
çalışmada, lise mezuniyeti neticesinde kamu sağlık hizmetleri sunumunda kişi başına 40,500 dolar (ömür boyu hesaplanan tutar) tasarruf edildiği belirtilmektedir (Levin vd., 2007: 9-10).

Eğitim seviyesinin etkileşim içinde olduğu bir diğer alan ise sosyal refah harcamalarıdır. Dezavantajlı gruplar içinde bulunan birçok kişi, devletin sunduğu sosyal yardımlardan faydalanmaktadır. Richard'a (2005) göre bu yardımlardan en fazla istifade edenler arasında bekâr ve liseyi terk etmiş anneler bulunmaktadır. Richard (2005) söz konusu annelerin liseyi bitirmeleri durumunda kamu idaresinin -yapılan yardımların azalması nedeniyle- yıllık 1.5 milyar dolar, bu annelerin üçte birinin üniversite eğitiminin herhangi bir basamağını tamamlaması durumunda ise 3.8 milyar dolar tasarruf edebileceğini ifade etmektedir.

Okul terki sebebiyle yeterli mesleki ve akademik bilgi düzeyine sahip olamayan bireyler iş hayatlarında birçok sorunla karşılaşmaktadır. Bunlardan en önemlisi düşük ücret gelirleridir. Hayatları boyunca bu düşük gelirin sebep olduğu birçok bireysel, sosyal ve ekonomik sorunla baş etmek durumunda kalmaları muhtemeldir. Diğer taraftan bu düşük gelirler, kamu gelirlerinin en önemli kaynağını oluşturan vergi gelirleri ve SGK primleri üzerinde de negatif yönlü bir etkiye neden olmaktadır.

\section{OKUL TERKININ KAMU GELİRLERİ AÇISINDAN DEĞERLENDİRILMESI}

\subsection{Literatür: Okul Terki ve Kamu Gelirleri}

Okul terkinin maliyetleri literatürde genellikle özel, mali ve sosyal maliyetler şeklinde sınıflandırılmaktadır. Kamu sektörü üzerinde yarattığı maliyetler ise sağlık harcamalarında artış, sosyal refah harcamalarında artış ve kamu gelirlerinde azalış şeklinde sıralanabilir.

Okul terki sonucunda yeterli akademik bilgi düzeyine ve meslek becerisine sahip olamayan bireyler daha düşük ücretlerle çalışmak durumunda kalmaktadır. Bu durum, bireyler açısından gelir kaybına neden olmaktadır. Cheeseman Day ve Newburger (2002) liseyi terk eden bireylerin, lise mezunlarına göre çalışma hayatları boyunca 270,000 dolar daha az gelir elde ettiklerini ortaya koymuşlardır.

Rouse (2005) ise çalışmasında, okul terki sonucunda kazançlarda yaşanan azalma dolayısıyla 158 milyar dolar gelir kaybının yaşandığını ifade etmektedir. Bu durumun da 36 milyar dolar eyalet ve federal gelir vergisi kaybına neden olduğunu belirtmektedir. Ayrıca çalışmada liseyi erken terk edenlerin, lise mezunlarına kıyasla yaklaşık 260,000 dolar daha az kazanç elde ettiği ve 60,000 dolar daha az vergi ödediği vurgulanmaktadır.

Levin vd. (2007) çalışmalarında, lise mezunlarının sağlayacakları faydaların temel bileşenlerini Amerika Birleşik Devletleri (ABD) özelinde ortaya koymuştur. Bu faydalardan ilki, 139,100 dolar tutarındaki ömür boyu toplam ekstra vergi ödemesidir. Bunun yanında 40,500 dolar halk sağlığı harcamalarında tasarruf, 26,600 dolar suç/adalet harcamalarında tasarruf ve öğrenciyi mezun olmaya teşvik için yapılan sosyal refah harcamalarında 3,000 dolar tasarruf diğer faydalar/kazanımlar arasındadır. Lise mezunu olma durumunda ise elde edilen ortalama sosyal getiri miktarı 209,200 dolar olarak ifade edilmektedir.

Tablo 5: Öğrenci Başına Lise Mezuniyeti Sonucunda Ortaya Çıkan Kazançlar/Tasarruflar Kazanç/Tasarruf 


\begin{tabular}{|c|c|}
\hline Ömür boyu vergi ödemesine katk1 & $139,100 \$$ \\
\hline $\begin{array}{l}\text { Halk sağlığına bağımlılığın azalması dolaysıyla elde edilen } \\
\text { tasarruf }\end{array}$ & $40,500 \$$ \\
\hline Azalan suç faaliyetleri dolayısıyla elde edilen tasarruf & $26,600 \$$ \\
\hline Sosyal refah harcamaları bağımlılığının azalması & $3,000 \$$ \\
\hline $\begin{array}{l}\text { Okul terkinin önlenmesi sonucunda elde edilen toplam } \\
\text { kazanç/tasarruf }\end{array}$ & $209,200 \$$ \\
\hline
\end{tabular}

Kaynak: Levin vd., 2007: 7-18.

Levin vd. (2007) tarafından ayrıca cinsiyete göre bir hesaplama da yapılmıştır. Buna göre liseyi terk eden erkek bireylerin ömür boyu ödeyeceği vergi miktarı yaklaşık 200,000 dolardır. Lise mezunu olan erkek bireyler ise ekstra 76,000 ila 153,000 dolar arasında vergi ödemektedir. Ayrıca üniversite mezunu olan erkek bireyler ekstra 503,000 ila 674,000 dolar arasında vergi ödemektedir. Liseyi terk eden kadın bireyler ise 100,000 doların altında ömür boyu vergi ödemektedir. Lise mezunu kadın bireyler ise 66,000 ila 84,000 dolar arasında ekstra vergi ödemektedir. Üniversite mezunu kadın bireylerin ise 348,000 ila 407,000 dolar arasında ekstra bir vergi ödeyeceği hesaplamalar sonucunda ortaya koyulmuştur.

Literatürde okul terkinin maliyetine yönelik ülkeler özelinde farklı çalışmalar da bulunmaktadır. Fransa özelinde 2013 yılında yayımlanan bir raporda, öğrenci başına okul terki maliyetinin 220,000 ila 230,000 euro (yaşam boyunca) arasında olduğu ortaya koyulmakla birlikte her yıl yaklaşık 140,000 öğrencinin okulu terk ettiği göz önüne alındığında ise gelecek beş yıl için yaklaşık 154 milyar euro bir maliyetin ortaya çıkacağı tahmin edilmiştir (Armand vd., 2013: 4). York Üniversitesi tarafından 2010 yılında yapılan bir araştırmaya göre ise eğitim ve istihdam dişında kalan bireylerin kamuya olan maliyeti yaklaşık 1.7 milyar pound olarak hesaplanmıştır. Söz konusu maliyetlerin eğitimde yetersizlik, işsizlik ve iktisadi faaliyette bulunmama nedeniyle eksik istihdamın bir sonucu olduğu ifade edilmektedir. Ayrıca bu kişilerin düşük tüketim harcamaları nedeniyle dolaylı vergi gelirlerini, istihdam piyasasında yer almadıkları için ise dolaysız vergi gelirlerini azalttığı vurgulanmaktadır. Kamu üzerindeki maliyetlerinin detaylarına bakıldığında ise bu kişilere yapılan işsizlik ödeneği ve konut yardımı ödemeleri öne çıkmaktadır (Coles vd., 2010: 16-17). Benzer bir çalışma Avrupa Birliği üyesi ülkeler özelinde de ortaya koyulmuş olup eğitimine devam etmeyen ve istihdam piyasasında yer almayan gençlerin AB üye ülke ekonomilerine maliyeti, 2008 yılı için yaklaşık 120 milyar euro (26 üye ülke için) olarak ifade edilmektedir. Söz konusu toplam tutar, üye ülkelerin toplam GSYH'nın \%1'ine tekabül etmektedir (Mascherini vd., 2012: 80-82).

\subsection{Kamu Gelir Kaybı ve Türkiye}

Türkiye'de uygulanmakta olan 12 yıllık zorunlu eğitim sistemi her ne kadar kesintisiz bir eğitim modeli olarak ön plana çıksa da okul terki oranlarının istenilen seviyede olmadığı ifade edilebilir. Bu durum On Birinci Kalkınma Planı (2019-2023)'nda yer alan “...ortaöğretimde okul terklerinin azaltılması ihtiyacı önemini korumaktadır." ifadesiyle de desteklenmektedir (www.sbb.gov.tr, 2020).

Okul terki, bireyler açısından işgücü piyasasında istihdam edilebilirlik düzeyini azaltarak daha düşük ücretler ile çalışmak zorunda kalınması sonucunu doğurur iken devletler açısından bu durumun karşılığı, vergi geliri ve sosyal parafiskal gelir (SGK primi) kaybı olarak ifade 
edilebilir. Dolayısıyla okul terkinin maliyeti kapsamında devletler açısından gelir kaybı düzeyinin belirlenmesi, bu sorunun farklı bir boyutunu ortaya koymaya da yardımcı olmaktadır. Literatürde okul terkine yönelik daha çok nedenler ve sonuçların ortaya koyulduğu sınırlı çalışmalar (Özer vd., 2011; Küçüker, 2018; Zorbaz ve Özer, 2020) olmakla birlikte okul terkinin maliyeti konusunda Türkiye özelinde herhangi bir çalışma bulunmamaktadır.

Çalışmanın bu bölümünde öncelikle okul terk sayıları belirlenerek bu veriler ışığında genel lise ve meslek lisesi mezuniyeti durumunda ortaya çıkan kamu gelir kaybı toplamı, 2018 y1lı verileri ile hesaplanmıştır. 2018 yılının seçilmiş olmasının gerekçesi ise hesaplamada kullanılan tüm değişkenlere ait verilerin ilgili yıl için elde edilebilir olmasıdır.

Türkiye'de 2018 yılı için okul terki sayıları; çağ nüfus yaşı ve okullaşma oranı verileri ile hesaplanarak Tablo 6'da sunulmuştur.

Tablo 6: Türkiye'de Ortaöğretim Düzeyinde Okul Terki Sayıları (2018)

\begin{tabular}{cccc}
\hline Yaş & Nüfus (Kişi) & Okullaşma Oranı (\%) & Okul Terki (Kişi) \\
\hline 14 & $1,225,127$ & 95.44 & 55,866 \\
\hline 15 & $1,204,096$ & 91.42 & 103,311 \\
\hline 16 & $1,222,888$ & 86.32 & 167,291 \\
\hline 17 & $1,309,109$ & 80.33 & 257,502 \\
\hline
\end{tabular}

Kaynak: Korlu, 2019; TÜİK, 2020, Adrese Dayalı Nüfus Kayıt İstatistikleri ve MEB Milli Eğitim İstatistikleri (2018-2019) kullanılarak tarafımızca hesaplanmıştır.

Tablo 6'ya bakıldığında Türkiye'de ortaöğretim düzeyinde okul terkinin 14 yaş grubunda en düşük seviyede olduğu ve yaş arttıkça bu sayının yükseldiği görülmektedir. 2018 yılı için toplam 583,970 öğrenci, eğitim sisteminin dışına çıkmıştır.

2018 yılı için eğitim sistemi dışında kalan öğrenci sayısı belirlendikten sonra kamu gelir kaybı (Vergi Geliri + SGK Primi) hesaplamasında kullanılacak bir diğer önemli veri olan eğitim durumuna göre elde edilen ücret, farklı mezuniyet türlerine göre Tablo 7'de sunulmuştur.

Tablo 7: Eğitim Durumuna Göre Aylık Ortalama Brüt Ücret (2018)

\begin{tabular}{ccc}
\hline \multicolumn{3}{c}{ Gelir (Brüt Aylık/TL) } \\
\hline İlkokul ve Ortaokul & Lise & Meslek Lisesi \\
\hline 2,804 & 3,011 & 4,061
\end{tabular}

Kaynak: TÜİK, 2020. http://tuik.gov.tr/PreTablo.do?alt_id=1008 (16.09.2020)

Eğitim durumuna göre bakıldığında; ilkokul ve ortaokul mezunlarının 2,804 TL (Brüt/Aylık), lise mezunlarının 3,011 TL (Brüt/Aylık) ve meslek lisesi mezunlarının 4,061 TL (Brüt/Aylık) ortalama gelir elde ettiği görülmektedir. Eğitim durumuna göre ortalama gelir belirlendikten sonra söz konusu gruplara ait ödenen yıllık vergi miktarı (Gelir Vergisi + Damga Vergisi) ile SGK kesintileri (SGK primi + işsizlik sigortası) ayrı ayrı hesaplanmıştır.

Türkiye'de; 193 Sayılı Gelir Vergisi Kanunu'nun 103. Maddesinde yer alan gelir vergisine tabi gelirlerden artan oranlı vergi tarifesine göre gelir vergisi hesaplanmaktadır. 2018 takvim y1lı için 14,800 TL'ye kadar \% 15; 34,000 TL'nin 14,800 TL'si için 2,220 TL, fazlas1 \% 20; 80,000 TL'nin 34,000 TL'si içim 6,060 TL, (ücret gelirlerinde 120,000 TL'nin 34,000 TL'si için 6,060 TL), fazlası \% 27; 80,000 TL'den fazlasının 80,000 TL'si için 18,480 TL, (ücret gelirlerinde 120,000 TL'den fazlasının 120,000 TL'si için 29,280 TL), fazlası \% 35 oranında tarife 
belirlenmiştir. Gelir vergisi dışında ücret gelirlerinden damga vergisi tahsil edilmektedir. 2018 y1lı damga vergisi oranı binde 7.59'dur (Resmi Gazete, 2020).

Ücret gelirleri üzerinden vergi kesintisinin yanında SGK kesintileri de yapılmaktadır. SGK kesintileri ise çalışan ve işveren payı olmak üzere ayrılmakta ve kesinti oranları değişmektedir. 2018 yılı için SGK primi çalışan payı \%14, işsizlik sigortası primi ise \%1 olarak uygulanmıştır. İşveren tarafında ise SGK primi işveren payı $\% 20.5^{1}$, işsizlik sigortası primi ise $\% 2$ oranında uygulanmaktadir.

Mezuniyet durumu ilkokul/ortaokul olan ve ücret geliri elde edilen kişilerin gelir vergisi, damga vergisi, SGK primi ve işsizlik sigortası primi (Çalışan/Işsveren) aylık olarak hesaplanarak bir hesap dönemi içinde toplam tutarları Tablo 8'de sunulmuştur.

Tablo 8: İlkokul/Ortaokul Mezuniyet Durumuna Göre Yıllık Vergi Miktarı ve SGK Primleri (2018)

\begin{tabular}{|c|c|c|c|c|c|c|c|}
\hline \multicolumn{8}{|c|}{ İlkokul / Ortaokul } \\
\hline & \multirow{3}{*}{$\begin{array}{l}\text { Brüt } \\
\text { Gelir }\end{array}$} & \multirow{3}{*}{$\begin{array}{l}\text { Aylık } \\
\text { Gelir } \\
\text { Vergisi }^{2}\end{array}$} & \multirow{3}{*}{$\begin{array}{l}\text { Damga } \\
\text { Vergisi }\end{array}$} & \multicolumn{2}{|c|}{ Çalışan } & \multicolumn{2}{|c|}{ İşveren } \\
\hline & & & & $S G K$ & İssizlik & $S G K$ & İssizlik \\
\hline & & & & Primi & Sigortast & Primi & Sigortasl \\
\hline Ocak & 2,804 & 205.3 & 21.28 & 392.56 & 28.04 & 574.82 & 56.08 \\
\hline Şubat & 2,804 & 205.3 & 21.28 & 392.56 & 28.04 & 574.82 & 56.08 \\
\hline Mart & 2,804 & 205.3 & 21.28 & 392.56 & 28.04 & 574.82 & 56.08 \\
\hline Nisan & 2,804 & 205.3 & 21.28 & 392.56 & 28.04 & 574.82 & 56.08 \\
\hline Mayıs & 2,804 & 205.3 & 21.28 & 392.56 & 28.04 & 574.82 & 56.08 \\
\hline Haziran & 2,804 & 205.3 & 21.28 & 392.56 & 28.04 & 574.82 & 56.08 \\
\hline Теттив & 2,804 & 299.49 & 21.28 & 392.56 & 28.04 & 574.82 & 56.08 \\
\hline Ăgustos & 2,804 & 324.47 & 21.28 & 392.56 & 28.04 & 574.82 & 56.08 \\
\hline Eylül & 2,804 & 324.47 & 21.28 & 392.56 & 28.04 & 574.82 & 56.08 \\
\hline Ekim & 2,804 & 324.47 & 21.28 & 392.56 & 28.04 & 574.82 & 56.08 \\
\hline Kasım & 2,804 & 324.47 & 21.28 & 392.56 & 28.04 & 574.82 & 56.08 \\
\hline Aralık & 2,804 & 324.47 & 21.28 & 392.56 & 28.04 & 574.82 & 56.08 \\
\hline Toplam & 33,648 & $3,153.64$ & 255.36 & $4,710.72$ & 336.48 & 6,897.84 & 672.96 \\
\hline
\end{tabular}

Kaynak: Tarafımızca oluşturulmuştur.

Buna göre ilkokul/ortaokul mezunu bir kişinin elde ettiği ücret gelirinden, yıllık 3,153.64 TL gelir vergisi, 255.36 TL damga vergisi, 4,710.72 TL SGK primi ve 336.48 TL işsizlik sigortası kesintisi yapılmaktadır. Ayrıca SGK primi işveren payı olarak 6,897.84 TL, işsizlik sigortası işveren payı olarak da 672.96 TL brüt ücret geliri üzerinden kesinti yapılmaktadır. Mezuniyet durumu orta öğretim (lise) olan ve ücret geliri elde eden kişilerin ücret gelirleri üzerinden tahsil edilen vergi ve SGK primleri Tablo 9'da sunulmuştur.

\footnotetext{
${ }^{1} 5510$ sayılı Kanunun 81. maddesinin (1) bendine göre, bentte belirtilen şartları sağlayan işverenlere, SGK primi işveren payında 5 puanlık indirim öngörülmekle birlikte gerekli şartları sağlamayan işverenler için, SGK primi işveren pay1 \%20,5'dir (ailevecalisma.gov.tr, 2020).

${ }^{2}$ Tüm hesaplamalarda, 2018 yılı Gelir Vergisi Tarifesi kullanılmış olup kişinin bekâr ve hiç çocuğunun olmadığı varsayılmıştır. Ayrıca gelir vergisi tutarı; Asgari Geçim İndirimi (AGI) düşülerek (2018 yılı için 152,21TL) hesaplamaya dâhil edilmiştir.

682
} 
Tablo 9: Lise Mezuniyet Durumuna Göre Yıllık Vergi Miktarı ve SGK Primleri (2018) Orta Öğretim (Lise)

\begin{tabular}{|c|c|c|c|c|c|c|c|}
\hline & \multirow[t]{2}{*}{ Brüt Gelir } & \multirow{2}{*}{$\begin{array}{l}\text { Aylik } \\
\text { Gelir } \\
\text { Vergisi }\end{array}$} & \multirow{2}{*}{$\begin{array}{l}\text { Damga } \\
\text { Vergisi }\end{array}$} & \multicolumn{2}{|c|}{ Çalışan } & \multicolumn{2}{|c|}{ İşveren } \\
\hline & & & & $\begin{array}{l}S G K \\
\text { Primi }\end{array}$ & $\begin{array}{l}\text { Issizlik } \\
\text { Sigortası }\end{array}$ & $\begin{array}{l}S G K \\
\text { Primi }\end{array}$ & $\begin{array}{l}\text { İssizlik } \\
\text { Sigortası }\end{array}$ \\
\hline Ocak & 3,011 & 231.69 & 22.85 & 421.54 & 30.11 & 617.26 & 60.22 \\
\hline Şubat & 3,011 & 231.69 & 22.85 & 421.54 & 30.11 & 617.26 & 60.22 \\
\hline Mart & 3,011 & 231.69 & 22.85 & 421.54 & 30.11 & 617.26 & 60.22 \\
\hline Nisan & 3,011 & 231.69 & 22.85 & 421.54 & 30.11 & 617.26 & 60.22 \\
\hline Mayıs & 3,011 & 231.69 & 22.85 & 421.54 & 30.11 & 617.26 & 60.22 \\
\hline Haziran & 3,011 & 259.50 & 22.85 & 421.54 & 30.11 & 617.26 & 60.22 \\
\hline Теттив & 3,011 & 359.66 & 22.85 & 421.54 & 30.11 & 617.26 & 60.22 \\
\hline Ăgustos & 3,011 & 359.66 & 22.85 & 421.54 & 30.11 & 617.26 & 60.22 \\
\hline Eylül & 3,011 & 359.66 & 22.85 & 421.54 & 30.11 & 617.26 & 60.22 \\
\hline Ekim & 3,011 & 359.66 & 22.85 & 421.54 & 30.11 & 617.26 & 60.22 \\
\hline Kasim & 3,011 & 359.66 & 22.85 & 421.54 & 30.11 & 617.26 & 60.22 \\
\hline Aralık & 3,011 & 359.66 & 22.85 & 421.54 & 30.11 & 617.26 & 60.22 \\
\hline Toplam & 36,132 & $3,575.91$ & 274.20 & $5,058.48$ & 361.32 & $7,407.12$ & 722.64 \\
\hline
\end{tabular}

Kaynak: Tarafımızca oluşturulmuştur.

Tablo 9'a bakıldığında lise mezunu bir kişinin elde ettiği ücret gelirinden y1llık 3,575.91 TL gelir vergisi, 274.20 TL damga vergisi, 5,058.48 TL SGK primi ve 361.32 TL işsizlik sigortası kesintisi yapıldığ görülmektedir. Bunun yanında, SGK primi işveren payı olarak 7,407.12 TL, işsizlik sigortası işveren payı olarak da 722.64 TL kesinti yapılmaktadır.

Mezuniyet durumu orta öğretim (meslek lisesi) olan ve ücret geliri elde edilen kişilerin gelir vergisi, damga vergisi, SGK primi ve işsizlik sigortası primi (Çalışan/Işsveren) aylık olarak hesaplanarak bir hesap dönemi içinde toplam tutarları Tablo 10'da sunulmuştur.

Tablo 10: Meslek Lisesi Mezuniyet Durumuna Göre Yıllık Vergi Miktarı ve SGK Primleri (2018) Orta Öğretim (Meslek Lisesi)

\begin{tabular}{|c|c|c|c|c|c|c|c|}
\hline & \multirow[t]{3}{*}{ Brüt Gelir } & \multirow{3}{*}{$\begin{array}{l}\text { Aylik } \\
\text { Gelir } \\
\text { Vergisi }\end{array}$} & \multirow{3}{*}{$\begin{array}{l}\text { Damga } \\
\text { Vergisi }\end{array}$} & \multicolumn{2}{|c|}{ Çalışan } & \multicolumn{2}{|c|}{ İşveren } \\
\hline & & & & $S G K$ & İşsizlik & $S G K$ & İşsizlik \\
\hline & & & & Primi & Sigortast & Primi & Sigortast \\
\hline Ocak & 4,061 & 365.57 & 30.82 & 568.54 & 40.61 & 832.51 & 81.22 \\
\hline Şubat & 4,061 & 365.57 & 30.82 & 568.54 & 40.61 & 832.51 & 81.22 \\
\hline Mart & 4,061 & 365.57 & 30.82 & 568.54 & 40.61 & 832.51 & 81.22 \\
\hline Nisan & 4,061 & 365.57 & 30.82 & 568.54 & 40.61 & 832.51 & 81.22 \\
\hline Mayıs & 4,061 & 488.53 & 30.82 & 568.54 & 40.61 & 832.51 & 81.22 \\
\hline Haziran & 4,061 & 538.16 & 30.82 & 568.54 & 40.61 & 832.51 & 81.22 \\
\hline Теттиz & 4,061 & 538.16 & 30.82 & 568.54 & 40.61 & 832.51 & 81.22 \\
\hline Ă̆ustos & 4,061 & 538.16 & 30.82 & 568.54 & 40.61 & 832.51 & 81.22 \\
\hline Eylül & 4,061 & 538.16 & 30.82 & 568.54 & 40.61 & 832.51 & 81.22 \\
\hline Ekim & 4,061 & 574.45 & 30.82 & 568.54 & 40.61 & 832.51 & 81.22 \\
\hline
\end{tabular}




\begin{tabular}{lccccccc}
\hline Kasım & 4,061 & 779.79 & 30.82 & 568.54 & 40.61 & 832.51 & 81.22 \\
\hline Aralık & 4,061 & 779.79 & 30.82 & 568.54 & 40.61 & 832.51 & 81.22 \\
\hline Toplam & $\mathbf{4 8 , 7 3 2}$ & $\mathbf{6 , 2 3 7 . 4 8}$ & $\mathbf{3 6 9 . 8 4}$ & $\mathbf{6 , 8 2 2 . 4 8}$ & $\mathbf{4 8 7 . 3 2}$ & $\mathbf{9 , 9 9 0 . 1 2}$ & $\mathbf{9 7 4 . 6 4}$ \\
\hline
\end{tabular}

Kaynak: Tarafimızca oluşturulmuştur.

Tablo 10'a göre meslek lisesi mezunu bir kişinin elde ettiği ücret gelirinden, y1llık 6,237.48 TL gelir vergisi, 369.84 TL damga vergisi, 6,822.48 TL SGK primi ve 487.32 TL işsizlik sigortası kesintisi yapılmaktadır. Ayrıca SGK primi işveren payı olarak 9,990.12 TL, işsizlik sigortası işveren payı olarak da 974.64 TL kesinti yapılmaktadır.

Yıllık vergi miktarı ve SGK prim tutarları, eğitim durumu değişkenine göre hesaplandıktan sonra mezuniyet türleri arasındaki farklılıklar Tablo 11'de sunulmuştur.

Tablo 11: Mezuniyet Durumuna Göre Yıllık Vergi ve SGK Prim Farkları (2018)

\begin{tabular}{|c|c|c|c|}
\hline & İlkokul/Ortaokul (a) & Lise (b) & Meslek Lisesi (c) \\
\hline Gelir Vergisi & $3,153.64 \mathrm{TL}$ & 3,575.91 TL & $6,237.48 \mathrm{TL}$ \\
\hline Damga Vergisi & $255.36 \mathrm{TL}$ & $274.2 \mathrm{TL}$ & $369.84 \mathrm{TL}$ \\
\hline Yillık Vergi Miktarl* & $3,409 \mathrm{TL}$ & 3,850.11 TL & 6,607.32 TL \\
\hline SGK Primi (Çalışan/İşveren) & $11,608.56 \mathrm{TL}$ & $12,465.6 \mathrm{TL}$ & $16,812.6 \mathrm{TL}$ \\
\hline $\begin{array}{l}\text { İşsizlik Sigortası } \\
\text { (Çalışan/İşveren) }\end{array}$ & $1,009.44 \mathrm{TL}$ & $1,083.96 \mathrm{TL}$ & $1,461.96 \mathrm{TL}$ \\
\hline Ylllk SGK Prim Miktarl ** & $12,618 \mathrm{TL}$ & 13,549.56 TL & $18,274.56 \mathrm{TL}$ \\
\hline Toplam Vergi Farki* (1) & 441.11 TL (b-a) & & $3,198.32$ TL (c-a) \\
\hline Toplam SGK Prim Farkl** (2) & 931.56 TL (b-a) & & $5,656.56$ TL (c-a) \\
\hline Kamu Gelir Farkı & $1,372.67 \mathrm{TL}(1+2)$ & & $8,854.88 \mathrm{TL}(1+2)$ \\
\hline
\end{tabular}

Kaynak: Tarafımızca hesaplanmıştır.

Tablo 11'e bakıldığında ilkokul/ortaokul sonrası eğitime devam edip en az lise mezunu olunmas1 (b-a) durumunda 441.11 TL, en az meslek lisesi mezunu olunması (c-a) durumunda ise 3,198.32 TL vergi farkı ortaya çıkmaktadır. Dolayısıyla ortaöğretim düzeyinde okul terki özellikle meslek lisesi mezunu ile ilkokul/ortaokul mezunu arasında vergi tutarında ciddi bir farkın olması- devletin önemli düzeyde bir vergi gelirinden mahrum kalmasına neden olmaktadir.

Vergi geliri yanında ücret gelirleri üzerinden tahsil edilen SGK primleri de eğitim durumuna göre önemli farklılıklar göstermektedir. Bu noktada ilkokul/ortaokul sonrası eğitime devam edip en az lise mezunu olunması (b-a) durumunda 931.56 TL, en az meslek lisesi mezunu olunması (c-a) durumunda ise 5,656.56 TL SGK prim farkı ortaya çıkmaktadır.

Eğitim durumuna göre vergi ve SGK prim farklılarının tamamı (toplam vergi geliri + toplam SGK prim) ele alındığında ise ilkokul/ortaokul sonrası eğitime devam edip en az lise mezunu olunması (b-a) durumunda 1,372.67 TL, en az meslek lisesi mezunu olunmasi (c-a) durumunda ise 8,854.88 TL kamu gelir kaybı ortaya çıkmaktadır.

Okul terkinin yol açtığı vergi ve SGK prim farklıklarını daha detaylı ve net bir şekilde ortaya koymak adına lise ve meslek lisesi ayrımı çerçevesinde 2018 yılı yükseköğretime geçiş ve 
istihdam oranları üzerinden değerlendirme yapmak yerinde olacaktır. Buna göre 2018 YKS okul türü ve yükseköğretim programlarına yerleşen aday sayıları Tablo 12'de sunulmuştur.

Tablo 12: Yükseköğretim Programlarına Yerleşen Aday Sayıları (2018)

\begin{tabular}{lcc}
\hline & Lise & Meslek Lisesi \\
\hline Lisans & 149,611 & 30,445 \\
\hline Ön lisans & 39,764 & 72,294 \\
\hline Açı Ö̈̆retim & 2,027 & 15,426 \\
\hline Toplam & $\mathbf{1 9 1 , 4 0 2}$ & $\mathbf{1 1 8 , 1 6 5}$ \\
\hline & & 483,162 \\
\hline Başvuran Öğrenci Sayısı & & $\mathbf{2 4 . 4 5}$ \\
\hline Yükseköğretime Geçiş Oranı (\%) & 471,191 &
\end{tabular}

Kaynak: MEB (2019), Milli Eğitim İstatistikleri 2018/2019.

Yükseköğretime geçiş oranlarına bakıldığında 2018 yılı yeni mezun olan lise öğrencilerinin yaklaşık \%40.62'si herhangi bir yükseköğretim programına yerleşmiş iken bu oranın meslek lisesi mezunlarında \%24.45 olarak gerçekleştiği görülmektedir.

Okul terki ile ilişkili olarak kamu gelir kaybını belirleme aşamasında bir diğer veri, istihdam oranlarıdır. 2018 yılı verilerine göre lise mezunlarının yaklaşı \% 46.5 'i istihdam edilirken bu oran meslek lisesi mezunları için \%57.5 olarak gerçekleşmiştir (TUIK, 2018).

$\mathrm{Bu}$ noktada hesaplanan ve elde edilen verilerle iki farklı mezuniyet durumuna göre 2018 yılı için okul terkinin yol açtığı vergi ve SGK prim kaybı ortaya koyulmuştur. İlk olarak 2018 yılı için hesaplamış olduğumuz eğitim dışı kalan 583,970 kişinin tamamının eğitime devam ederek en az lise mezunu olduğu durum ele alınmış, sonrasında ise söz konusu okul terki yapan kişilerin tamamının en az meslek lisesi mezunu olma durumu hesaplanmıştır.

2018 yılı eğitim dışı kalan 583,970 kişinin eğitimine devam edip en az lise mezunu ve/veya meslek lisesi mezunu olması durumunda toplam vergi ve SGK prim farkı ile kamu gelir kaybı toplamı Tablo 13'te özetlenmiştir.

Tablo 13: Kamu Gelir Kaybı (2018)

\begin{tabular}{|c|c|c|c|c|c|}
\hline \multicolumn{4}{|c|}{ Lise } & \multicolumn{2}{|c|}{ Meslek Lisesi } \\
\hline $\begin{array}{l}\text { Okul Terki } \\
\text { (Kişi) }\end{array}$ & & 583,970 & $\begin{array}{l}\text { Okul Terki } \\
\text { (Kişi) }\end{array}$ & & 583,970 \\
\hline $\begin{array}{l}\text { Yüksekögretime } \\
\text { Geçiş Oranı (\%) }\end{array}$ & $\begin{array}{c}40.62 \\
(237,209 \\
\text { Kişi) }\end{array}$ & 346,761 & $\begin{array}{l}\text { Yüksekögretime } \\
\text { Geçiş Oranı (\%) }\end{array}$ & $\begin{array}{c}24.45 \\
(142,781 \\
\text { Kişi) }\end{array}$ & 441,189 \\
\hline 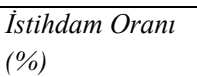 & 46.5 & 161,243 & $\begin{array}{l}\text { Istihdam Oranı } \\
(\%)\end{array}$ & 57.5 & 253,684 \\
\hline $\begin{array}{l}\text { Toplam Vergi } \\
\text { Farkl }\end{array}$ & $\begin{array}{l}441.11 \mathrm{TL} \\
\quad(\mathrm{b}-\mathrm{a})\end{array}$ & $71,125,900 \mathrm{TL}$ & $\begin{array}{l}\text { Toplam Vergi } \\
\text { Farkı }\end{array}$ & $\begin{array}{c}3,198.32 \\
\text { TL } \\
(\mathrm{c}-\mathrm{a})\end{array}$ & $811,362,610 \mathrm{TL}$ \\
\hline $\begin{array}{l}\text { Dolar Kuru } \\
(2018 \text { Yllı Ort. })^{4}\end{array}$ & $4.82 \$ / \mathrm{TL}$ & 14.7 Milyon \$ & $\begin{array}{l}\text { Dolar Kuru } \\
\text { (2018 Yllı Ort.) }\end{array}$ & $4.82 \$ / \mathrm{TL}$ & 168.3 Milyon \$ \\
\hline
\end{tabular}

${ }^{3}$ Son sınıf düzeyinde (yeni mezun) aday sayıları baz alınmıştır.

${ }^{4}$ Türkiye Cumhuriyet Merkez Bankası, (2020), https://evds2.tcmb.gov.tr/index.php?/evds/serieMarket (19.07.2020). 
BAKIRTAŞ \& NAZLIOĞLU

\begin{tabular}{|c|c|c|c|c|c|}
\hline $\begin{array}{l}\text { Kişi Başına Vergi } \\
\text { Farkı (\$) }\end{array}$ & & $91.5 \$$ & $\begin{array}{l}\text { Kişi Başına Vergi } \\
\text { Farkı (\$) }\end{array}$ & & $663.5 \$$ \\
\hline $\begin{array}{l}\text { Toplam SGK Prim } \\
\text { Farkı }\end{array}$ & $\begin{array}{c}931.56 \mathrm{TL} \\
(\mathrm{b}-\mathrm{a})\end{array}$ & $150,207,529 \mathrm{TL}$ & $\begin{array}{l}\text { Toplam SGK Prim } \\
\text { Farkı }\end{array}$ & $\begin{array}{c}5,656.56 \\
\mathrm{TL} \\
(\mathrm{c}-\mathrm{a})\end{array}$ & $1,434,978,767 \mathrm{TL}$ \\
\hline $\begin{array}{l}\text { Dolar Kuru } \\
\text { (2018 Yllı Ort.) }\end{array}$ & $4.82 \$ / \mathrm{TL}$ & 31.1 Milyon \$ & $\begin{array}{l}\text { Dolar Kuru } \\
\text { (2018 Yllı Ort.) }\end{array}$ & $4.82 \$ / T L$ & 297.7 Milyon \$ \\
\hline $\begin{array}{l}\text { Kişi Başına SGK } \\
\text { Prim Farkı (\$) }\end{array}$ & & $193.2 \$$ & $\begin{array}{l}\text { Kişi Başına SGK } \\
\text { Prim Farkı (\$) }\end{array}$ & & $1,173.5 \$$ \\
\hline $\begin{array}{l}\text { Kamu Gelir Kaybı } \\
\text { Toplamı }\end{array}$ & & 45.9 Milyon \$ & $\begin{array}{l}\text { Kamu Gelir Kaybı } \\
\text { Toplamı }\end{array}$ & & 466 Milyon \$ \\
\hline $\begin{array}{l}\text { Kişi Başına Kamu } \\
\text { Gelir Kaybı }\end{array}$ & & $284.8 \$$ & $\begin{array}{l}\text { Kişi Başına } \\
\text { Kamu Gelir Kaybı }\end{array}$ & & $1,837 \$$ \\
\hline
\end{tabular}

Kaynak: Tarafimızca oluşturulmuştur.

2018 yılı eğitim dışı kalan 583,970 kişinin eğitimine devam edip en az lise mezunu olduğu varsayımı altında öncelikle yükseköğretime geçiş yapan/yapacak kişi sayısı (yaklaşık 237,209 kişi) toplam okul terki sayısından düşülmüştür. Yükseköğretime devam etmeyen 346,761 kişinin 2018 yılı ortalama istihdam oranları baz alındığında yaklaşık 161,243 kişinin bir iş kolunda çalıştığı/çalışabileceği ve ücret geliri elde ettiği/edebileceği söylenebilir. Bu durumda istihdam edilen 161,243 lise mezununun y1llık vergi miktarı $(3,850.11 \mathrm{TL})$ ile ilkokul/ortaokul mezunlarının yıllık vergi miktarı $(3,409 T L)$ arasındaki fark 441.11 TL olup, toplam vergi farkı 71,125,900 TL $(161,243 * 441.11 \mathrm{TL})$ olmaktadır. 2018 y1lı ortalama dolar/TL kuru baz alındığında ise vergi farkının yaklaşık 14.7 milyon dolar olduğu ifade edilebilir. Kişinin, lise mezunu olmayıp ilkokul/ortaokul mezunu olması durumunda kişi başına vergi farkı ise yaklaşık 91.5 \$ olmaktadır.

SGK primleri açısından bakıldığında ise, istihdam edilen 161,243 lise mezununun yıllık SGK prim miktarı $(13,549.56 \mathrm{TL})$ ile ilkokul/ortaokul mezunlarının yıllık SGK prim miktarı $(12,618$ $T L)$ arasındaki fark 931.56 TL olup, toplam SGK prim fark1 150,207,529 TL $(161,243 * 931.56$ $T L)$ olmaktadır. 2018 yılı ortalama dolar/TL kuru baz alındığında ise SGK prim farkının yaklaşık 31.1 milyon dolar olduğu söylenebilir. Bununla birlikte, kişinin lise mezunu olmayıp ilkokul/ortaokul mezunu olması durumunda kişi başına kamu gelir kaybının 284.8 \$ olduğu ifade edilebilir.

Eğitim dışı kalan 583,970 kişinin eğitimine devam edip en az meslek lisesi mezunu olduğu varsayımı altında ise yükseköğretime devam etmeyen 441,189 kişinin 2018 y1lı ortalama istihdam oranları baz alındığında yaklaşık 253,684'ünün bir iş kolunda çalıştığı/çalışabileceği ve gelir elde ettiği/edebileceği söylenebilir. Bu durumda istihdam edilen 253,684 meslek lisesi mezununun yıllık vergi miktarı $(6,607.32 \mathrm{TL})$ ile ilkokul/ortaokul mezunlarının yıllık vergi miktarı (3,409 TL) arasındaki fark 3,198.32 TL olup, toplam vergi fark1 811,362,610 TL $(253,684 * 3,198.32 T L)$ olmaktadır. 2018 yılı ortalama dolar/TL kuru baz alındığında ise vergi farkının yaklaşık 168.3 milyon dolar olduğu ifade edilebilir. Kişinin meslek lisesi mezunu olmayıp ilkokul/ortaokul mezunu olması durumunda kişi başına vergi farkı ise yaklaşık 663.5 \$ olmaktadır.

SGK primleri açısından bakıldığında ise, istihdam edilen 253,684 meslek lisesi mezununun yıllık SGK prim miktarı $(18,274.56 \mathrm{TL})$ ile ilkokul/ortaokul mezunlarının yıllık SGK prim miktarı $(12,618 T L)$ arasındaki fark 5,656.56 TL olup, toplam SGK prim fark1 1,434,978,767 
TL $(253,684 * 5,656.56$ TL) olmaktadır. 2018 yılı ortalama dolar/TL kuru baz alındığında ise SGK prim farkının yaklaşık 297.7 milyon dolar olduğu söylenebilir. Bununla birlikte, kişinin meslek lisesi mezunu olmayıp ilkokul/ortaokul mezunu olması durumunda kişi başına kamu gelir kaybının 1,837 \$ olduğu ifade edilebilir.

\section{DEĞERLENDİRME VE SONUÇ}

Okul terki, toplumsal gelişmenin önündeki en büyük engellerden biri olarak kabul edilmektedir. Okul terki sebebiyle yeterli düzeyde akademik ve mesleki eğitim alınamaması bireysel, mali ve sosyal birçok maliyete neden olmaktadır. Dolayısıyla bu durum bir taraftan toplumsal ve ekonomik açıdan verimliliğin ve rekabetin gerilemesine, diğer taraftan yoksulluğun artmasına ve kamu kaynaklarının optimal kullanılamamasına neden olmaktadır.

Çalışmada, 2018 yılı ortaöğretim dönemi için eğitim dışında kalan kişi sayısı hesaplanmış olup söz konusu kişilerin eğitimlerine devam etmesi varsayımı altında mezuniyet durumuna göre vergi ve SGK prim tutarı farklılıkları ortaya koyulmuştur. Buna göre lise ile ilkokul/ortaokul mezunları arasında 441.11 TL vergi fark1, 931.56 TL SGK prim farkı olmak üzere toplam 1,372.67 TL kamu gelir kaybı ortaya çıkmaktadır. Meslek lisesi ile ilkokul/ortaokul mezunları arasında ise kamu gelir kaybı 3,198.32 TL vergi ve 5,656.56 TL SGK prim farkı olmak üzere toplam 8,854.88 TL olarak hesaplanmıştır. Söz konusu farklar belirlendikten sonra ise mezuniyet durumlarına göre yükseköğretime geçiş oranları hesaplanmış ve üniversite eğitimine devam etmeyen kişi sayısı, öğrenim durumuna göre istihdam oranları kapsamında işgücüne dâhil olduğu varsayılmıştır. Bu varsayımdan hareketle, ortaöğretim düzeyinde okul terkinin olmadığı ve mevcut durumda hesapladığımız okulu terk edenlerin tamamının en az lise mezunu olduğu durumda kamu gelir kaybı -elde edilen ortalama ücret gelirine göre- 2018 yılı için yaklaşık 45.9 milyon dolar, okulu terk edenlerin tamamının en az meslek lisesi mezunu olduğu durumda ise yaklaşık 466 milyon dolar olarak hesaplanmıştır. Kişi başına kamu gelir kaybı ise en az lise mezunu olma durumunda 284.8 \$ en az meslek lisesi mezunu olma durumunda ise 1,837 \$ olduğu söylenebilir.

Okul terkinin maliyetine yönelik bu öncü çalışma özelinde her ne kadar kamu gelir kaybı ortaya koyulmaya çalışılmış olsa da bazı sınırlılıkların olduğunu söylemek mümkündür. Öncelikle vergi gelirleri açısından bakıldığında çalışmada yalnızca ücret gelirleri üzerinden tahsil edilen gelir vergisi ve damga vergisi hesaplamasına yer verilmiştir. Söz konusu vergilerin yanında diğer vergi türleri olan harcama ve servet vergileri, çalışma kapsamına dâhil edilmemiş olup gelir elde edilmesi ile birlikte tüketim harcamalarının yapılması/yapılacak olması ve/veya servet ediniminin olacağı açıktır. Dolayısıyla kamu gelirleri açısından bakıldığında özellikle tüketim harcamaları sonucunda katma değer vergisi (KDV) ve özel tüketim vergisi (ÖTV) gibi vergi türlerinin de önem arz ettiği ifade edilebilir. Ayrıca gelir, harcama ve servet vergilerinin tamamının hesaplamaya dâhil edilmesi durumunda kamu gelir kaybının artacağı da rahatlıkla söylenebilir. Bunun yanında hesaplamada ortalama aylık/brüt ücret değişkeni kullanılmıştır. Ancak piyasa koşulları ve genel işleyişi göz önüne alındığında işe yeni başlamış bir çalışan ile tecrübeli çalışanlar arasında bir ücret farkının olacağını söylemek mümkündür. Ancak söz konusu farklılıklara yönelik detaylı verilere ulaşmak mümkün olmamaktadır. Benzer şekilde, sektör farklılıklarına göre ücretler de değişmektedir. Bununla birlikte, okul terkinin toplum ve kamu bütçesi üzerindeki maliyetlerini yalnızca vergi geliri ve SGK primleri ile değil, bilgi ve kültürel altyapı eksikliği çerçevesinde niteliksiz işgücü, suça yönelme eğilimleri, kayıt dış1 ekonomi, sağlık hizmetlerinin sunumu ve kişi başına düşen eğitim harcamalarının verimsizliği gibi birçok toplumsal maliyet unsuru olan ve kamu bütçesini aşındırıcı faktör üzerinden 
değerlendirmek de önem arz etmektedir. Dolayısıyla gelecekte bu alanda çalışacak araştırmacıların okul terkinin maliyeti kapsamında farklı maliyet unsurlarını bir bütün halinde analiz etmeye çalışması yerinde olacaktır.

\section{KAYNAKÇA}

ANDERSON, D. M. (2014). "In School and Out Of Trouble? The Minimum Dropout Age and Juvenile Crime", Review of Economics and Statistics, 96(2), 318-331.

ARMAND, A., BISSON-VAIVRE, C. \& LHERMET, P. (2013). "Agir contre le décrochage scolaire: alliance éducative et approche pédagogique repensée", Rapport à Monsieur le, file:///C:/Users/dqn/Downloads/agir-contre-le-d-crochage-scolaire-allianceducative-et-approche-p-dagogique-repens-e-44216.pdf (15.09.2020)

ASLUND, O., GRÖNQVIST, H., HALL, C. \& VLACHOS, J. (2018). “Education and Criminal Behavior: Insights from An Expansion”, Labour Economics, 52, 178-192.

BATSCHE, C. (1985). The High School Drop Out: Vocational Education Can Help. Illinois State Board of Education.

BELFIELD, C. (2008). “The Cost of Early School-leaving and School Failure”, New York: World Bank.

BRIDGELAND, J. M., DILUHIO Jr, J. J. \& MORISON, K.B. (2006). "The Silent Epidemic: Perspectives of High School Dropouts", Washington: Bill \& Melinda Gates Foundation.

BRUNELLO, G. \& DE PAOLO, M. (2014). “The Costs of Early School Leaving in Europe”. IZA Journal of Labor Policy, 3-22.

CARBONARO, W. \& WORKMAN, J. (2013). "Dropping Out of High School: Effects of Close and Distant Friendships", Social Science Research, 42(5), 1254-1268.

CATTERALL, J. S. (1985). "On the social costs of dropping out of school (CERAS Report No:86-SEPI-3)”, Stanford: Stanford University, School of Education.

CHAPLIN, D. \& LERMAN, R. (1997). "Dropping out: Public and private costs", Eastern Economics Association Meeting. Washington, DC.

CHEESEMAN DAY, J. \& NEWBURGER, E.C. (2002). "The big payoff: Educational Attainment and Synthetic Estimates of Work-Life Earnings”, Washington, DC: US Census Bureau.

COLES, B., GODFREY, C., KEUNG, A., PARROTT, S. \& BRADSHAW, J. (2010). "Estimating the life-time cost of NEET: 16-18 year olds not in Education, Employment or Training", York: University of York.

CREATE (2009). "Dropping Out From School: Policy Brief Number 8. Consortium for Research on Education, Access, Transitions and Equity", http://www.createrpc.org/pdf_documents/Policy_Brief_8.pdf (19.08.2020).

CUTLER, D. M. \& LLERAS-MUNEY, A. (2006). "Education and Health: Evaluating Theories and Evidence", National Bureau of Economic Research (NBER Working Paper No. 12352). 
DAHL, G. B. (2005). "Early Teen Marriage and Future Poverty”, National Bureau of Economic Research (NBER Working Paper No. 11328).

DEKKERS, H. \& CLAASSEN, A. (2001). "Dropouts-Disadvantaged By Definition? A Study of The Perspective of Very Early School Leavers", Studies in Educational Evaluation, 27, 341-354.

EUROPEAN COMMISSION (2011). "Data Collection on and Monitoring of Early School Leaving (ESL)”, European Commission.

EUROSTAT (2020), "Early Leavers From Education and Training”, https://ec.europa.eu/eurostat/statisticsexplained/index.php/Early_leavers_from_educ ation_and_trainig (Erişim Tarihi: 16.08.2020).

KAUFMANN, J. J. \& LEWIS, M. V. (1968). “The School Environment and Its Influence on Educational Programs for High School Dropouts”, U.S. Department of Health Education and Welfare, Office of Education Bureau of Research.

KÜÇÜKER, E. (2018). “Kırsal Kesimde Yaşayan Kız Çocukların Örgün Ortaöğretimi Terk Etme Nedenleri”. Eğitim ve Bilim, 43(195), 97-117.

KORLU, Ö. (2019). “Bir Bakışta Eğitim 2019'a Göre Türkiye’de Eğitimin Durumu”, https://www.egitimreformugirisimi.org/yayin/bir-bakista-egitim-2019a-goreturkiyede-egitimin-durumu/ (06.09.2020).

LEVIN, H., BELFIELD, C., MUENNIG, P. \& ROUSE, C. (2007). “The Costs of Benefits of An Excellent Education for All of America's Children”, Lilo and Gerry Leeds to Teachers College, Columbia University.

MASCHERINI, M., SALVATORE, L., MEIERKORD, A. \& JUNGBLUT, J. M. (2012). "NEETs: Young people not in employment, education or training: Characteristics, costs and policy responses in Europe", Luxembourg: Publications Office of the European Union.

MCNEAL Jr, R. B. (1997). "High School Dropouts: A Closer Examination of School Effects”, Social Science Quarterly, 78(1), 209-222.

MERTENS, D. M., SEITZ, P. \& COX, S. (1982). "Vocational Education and The High School Dropout", Columbus: The National Center for Research in Vocational Education The Ohio State University.

MİLLİ EĞİTİM BAKANLIĞI (MEB) (2013). "Ortaöğretimde Sınıf Tekrarı, Okul Terk Sebepleri ve Örgün Eğitim Dışında Kalan Çocuklar Politika Önerileri Raporu”, https://www.meb.gov.tr/meb_iys_dosyalar/2014_07/07035316_politikaraporu_baski _final.pdf (Erişim Tarihi: 16.06.2020).

MİLLİ EĞİTİM BAKANLIĞI (MEB) (2020). “Milli Eğitim İstatistikleri (2018-2019)”, http://sgb.meb.gov.tr/www/icerik_goruntule.php?KNO=361 (19.07.2020).

MORETTI, E. (2005). “Does Education Reduce Participation in Criminal Activities?”, Social Costs of Inadequate Education Symposium, http://www.equitycampaign.org/eventspage/equity-symposia/2005-the-social-costs-of-inadequateeducation/papers/74_Moretti_Symp.pdf (19.07.2020). 
NATSEM (1999). "The Cost to Australia of Early School-Leaving/Technical Paper”, Canberra: University of Canberra.

OECD (2010), “Overcoming School Failure: Policies That Work”, OECD.

ÖZER, A., GENÇTANIRIM, D. ve ERGENE, T. (2011). "Türk Lise Öğrencilerinde Okul Terkinin Yordanması: Aracı ve Etkileşim Değişkenleri ile Bir Model Testi”, Eğitim ve Bilim, 36(161), 302-317.

PSACHAROPOULOS, G. (2007). "The Costs of School Failure-A Feasibility Study (EENEE Analytical Report No. 2)", European Expert Network on Economics of Education (EENEE).

RESMİ GAZETE (2020). “Gelir Vergisi Genel Tebliği”, https://www.resmigazete.gov.tr/eskiler/2018/12/20181231M3-12.htm (Erişim Tarihi: 16.08.2020).

RESTA, M. \& TEMPLE, J. (1978). "Dropout Rates Among Students Enrolled in New Mexico Secondary Vocational Education Programs", Albuquerque: Institute for Applied Research Services, University of New Mexico.

RICHARD, A. (2005). "Researchers Tally Costs of Education Failings", Education Week, 25(10), 6-7.

ROTERMUND, S. (2007). "Why students drop out of high school: Comparisons from three national (Statistical Brief Number 2)", University of California Linguistic Minority Research Institute.

ROUSE, C. (2005). “Labour Market Consequences of an Inadequate Education”, Social Costs of Inadequate Education. Teachers College Columbia University.

RUMBERGER, R. W. (1987). "High School Dropouts: A Review of Issues and Evidence”, Review of Educational Research, 57(2), 101-121.

RUMBERGER, R. W. (1995). "Dropping out of Middle School: A Multilevel Analysis of Students and Schools", American Education Research Journal, 32(3), 583-625.

RUMBERGER, R. W. (2001). "Why Students Drop Out of School and What Can be Done", Dropouts in America: How Severe is the Problem? What Do We Know about Intervention and Prevention? Harvard University.

RUMBERGER, R. W. \& LIM, S. A. (2008). "Why Students Drop Out of School: A Review of 25 Years of Research (California Dropout Research Project Report \#15)", Santa Barbara: University of California Linguistic Minority Research Institute.

RUMBERGER, R. W., Ghatak, R., Poulos, G., Ritter, P. ve Dornbusch, S. M. (1990). "Family Influences on Dropout Behavior in One California High School", Sociology of Education, 63, 283-299.

SMITH, D. L. \& AMENT, P. A. (1990). “At Risk Secondary Students and Impact of Occupational Education”, Carson City: Nevada State Dept. of Education.

SNYDER, H. N. \& SICKMUND, M. (1999), “Juvenile Offenders and Victims: 1999 National Report”, US Department of Justice.

690 
T.C. AİLE, ÇALIŞMA VE SOSYAL HİZMETLER BAKANLIĞI (2020). “Asgari Ücretin Net Hesabı ve İşverene Maliyeti”, https://www.ailevecalisma.gov.tr/media/35788/asgariucretin-net-hesabi-ve-isverene-maliyeti-2020-01012020-31122020.pdf (Erişim Tarihi: 16.09.2020).

T.C. CUMHURBAŞKANLIĞI STRATEJİ VE BÜTÇE BAŞKANLIĞI (2020). "On Birinci Kalkınma Planı (2019-2023)", $\quad$ http://www.sbb.gov.tr/wp content/uploads/2019/07/OnbirinciKalkinmaPlani.pdf (19.07.2020).

TÜRKIYE CUMHURIYET MERKEZ BANKASI, (2020), “Kurlar”, https://evds2.tcmb.gov.tr/index.php?/evds/serieMarket (19.07.2020).

TÜRKIYE İSTATISTIIK KURUMU (TÜIK) (2020). “Adrese Dayalı Nüfus Kayıt İstatistikleri”, http://www.tuik.gov.tr/PreTablo.do?alt_id=1059 (16.09.2020).

VARNER, S. E. (1967), "School Dropouts", Washington, D.C.: National Education Association.

WEIS, L., FARRAR, E. ve PETRIE, H. G. (1989). "Dropouts From School: Issues, Dilemmas and Solutions", New York: State University of New York Press.

ZORBAZ, O. \& ÖZER, A. (2020). “Okul Terk Riskini Etkileyen Öğrenci Özellikleri, Bir Okuldan Diğerine Farklı Mıdır?”, Eğitim ve Bilim, 45(202), 191-210. 